\title{
Effects of 10-Week Whole Body Vibration Training on Strength, Flexibility and Agility in Taekwondo Athletes
}

\author{
Duygu Aksoy ${ }^{1}$ \\ ${ }^{1}$ School of Physical Education and Sports, Namik Kemal University, Tekirdag, Turkey \\ Correspondence: Duygu Aksoy, School of Physical Education and Sports, Namik Kemal University, Tekirdag, \\ Turkey. E-mail: duyguaksoy@nku.edu.tr
}

Received: February 10, 2019

Accepted: March 2, 2019 Online Published: March 6, 2019

doi:10.5539/jel.v8n2p213

URL: https://doi.org/10.5539/jel.v8n2p213

\begin{abstract}
Whole Body Vibration (WBV) is a type of exercise commonly applied as a modern exercise technique. The purpose of the present study was to examine the effects of WBV applied for 10-week on strength, flexibility and agility in taekwondo athletes. A total of 23 healthy young males participated in the present study. The athletes were separated randomly into two groups as the control group $(\mathrm{n}=11)$ and whole body vibration training group $(\mathrm{n}=12)$. The WBV training group did training 3 days a week for 10 weeks. The Control Group did not do any trainings. The hand grip strength test, vertical jump test, sit-reach test, agility t-test were applied to the WBV training group and control group before and after the 10-week WBV training. The comparisons between the groups were analyzed by using an independent sample t-test at a significance level of $p<0.05$. No statistically significant differences were detected between the pre-test hand grip strength, vertical jump test, sit-reach test and agility t-test results of the WBV training group and control group according to the Independent sample $t$ test. In the post-test results, statistically significant differences were detected between the vertical jump test, sit-reach test, agility t-test however, no statistically significant differences were detected between the hand grip strength results. The intra-group comparisons were made according to the paired sample $t$ test at a significance level of $\mathrm{p}<0.05$. Although statistically significant differences were detected in the WBV training group between the pre-test-post-test, vertical jump test, sit-reach test, agility t-test values, no statistically significant differences were detected between the hand grip strength results. No statistically significant differences were detected between the hand grip strength, vertical jump, sit-reach, agility t-test pre-test and post-test results of the control group. Long-term whole body vibration training has positive strength, flexibility and agility values.
\end{abstract}

Keywords: whole body vibration training, vertical jump, hand grip, sit-reach test, agility t-test, taekwondo

\section{Introduction}

Whole Body Vibration (WBV) is a type of exercise applied as a modern exercise technique. Provided that the amplitude and frequency are used within proper ranges, WBV has been used as a type of exercise as of 1990s (Roelants et al., 2004a). WBV training is done on a special platform. In different studies, vibration platforms are used with static positions, with an additional load or with dynamic movements (Rittweger et al., 2001; Ronnestad, 2004).

WBV is a frequently used exercise modality employed in fitness and health centers for the purpose of increasing muscle strength and balance (Machado et al., 2010; Sitjà-Rabert et al., 2012; Delecluse et al., 2003; Petit et al., 2010; Bosco et al., 1998; Mahieu et al., 2006; Giorgos et al., 2007; Savelberg et al., 2007; Luo et al., 2005; Adams et al., 2009), and flexibility (Fagnani et al., 2006; Dallas et al., 2012; Behm et al., 2011; Siegmund et al., 2014; Samson et al., 2012; Dadebo et al., 2004; Torvinen et al., 2002).

In Taekwondo, the basic aim is to improve war skills and techniques of soldiers; to give warrior trainings to individuals. It was first used in Korea, and then began to spread all over the world especially after the Korean War. It has been transformed from its traditional structure to modern sense as of 1950 (Shirley \& Gabriel, 2011). Taekwondo is a Korean martial art sport which has become a full-medal sport at 2000 Summer Olympics for the first time in Sydney as an Olympic Sport (Kwok, 2012).

Few acute WBV trainings were performed on elite athletes when compared to untrained individuals. According to the literature, it was reported that the vertical jump height and power (Despina et al., 2014; Cochrane \& 
Stannard; 2005; Bosco et al., 1999), flexibility (George et al., 2012; Dallas \& Kirialanis, 2013; Cochrane, 2005) and Hand grip (Issurin et al., 1994; Kvorning et al., 2006) values increased in trained athletes after WBV training. However, it was also reported in some previous studies that there were no changes or a significant performance decrease was detected in vertical jump, power performance (Margarita et al., 2013; Dallas \& Kirialanis, 2013; Bullock et al., 2008), and flexibility (Margarita et al., 2013). It was also reported in the literature that long-term WBV training increased vertical jump scores of basketball players (Fort et al., 2012; Frenandez et al., 2012; Colson et al., 2010) as well as some studies reporting that no significant differences were detected. Most of the studies examined the vertical jump scores of basketball players. In the literature, we could not detect any studies with which we can compare the effects of long-term WBV training on flexibility, agility and hand grip strength. In addition, there were no studies conducted on the effects of long term WBV training on Taekwondo athletes.

The purpose of the present study was to examine the effects of 10-week Whole Body Vibration Training on strength, flexibility and agility in taekwondo athletes.

\section{Materials and Methods}

\subsection{Participants}

A total of 23 volunteering male taekwondo athletes who did not do regular sports and who did not have any health problems participated in the study.

A total of 23 male taekwondo athletes who were included in the study as the WBV training group (average age $22.12 \pm 1.93$, average height $175.11 \pm 4.11 \mathrm{~cm}$., body weights $71.45 \pm 13.11 \mathrm{~kg}$., training experience $9.3 \pm 3.2$ years). The control group (age $21.33 \pm 2.84$, average height $175.51 \pm 6.41 \mathrm{~cm}$., body weight $71.52 \pm 16.14 \mathrm{~kg}$., training experience: $9.5 \pm 4.1$ years) consisted of 23 healthy male taekwondo athletes who agreed to participate in the study voluntarily, who did not have any neurological health problems.

The participants were separated randomly into two groups; the WBV training group $(n=12)$ and the control group $(\mathrm{n}=11)$. The exclusion criteria were having any types of prostheses, having muscular or neurological diseases that affects bone metabolism, having chronic inflammatory diseases and having no injury or medical surgery related to lower and upper extremities that could affect the test results, and having no participation in other exercise programs in the last month. None of the subjects had previous experience with WBV. A document was given to the participants in which their voluntary participation was asked and information was provided on the tests to be applied in the study. Detailed information was given to the participants. It was made sure that the volunteers were informed about the proceedings during the study. In addition, informed consent forms were also given to the participants. All the participants signed the informed consent form according to the Helsinki Declaration.

\subsection{Study Procedure}

The WBV training group did training 3 days a week for 10 weeks. The control group did not do any training.

For both groups, the first measurements of height, weight, vertical jump, hand grip strength, sit-reach and agility t-test were made before the training program started. The post-measurements were made after the 10 -week Whole Body Vibration Training, following the last training day between the 24 and 48th hours. The trainings started with a 5 min jogging warm-up on a treadmill, lower and upper body stretching exercises.

The participants were asked not to eat within the last $1.5 \mathrm{~h}$ before the tests, and not to engage in any vigorous training on the day before the tests; however, they were allowed to drink water in all tests. All athletes were tested at the same research laboratory to ensure that the testing setting was constant.

\subsection{Whole Body Vibration Training}

The WBV training was carried out on Vibration Platform (Power-Plate, Pro5, USA). The WBV training group jogged for 5 minutes, and did stretching exercises for 10 minutes prior to the vibration training. There were 6 exercises in the vibration training program. Training volume and training intensity of the WBV training program are shown in Table 1. 
Table 1. Training volume and training intensity of the Whole Body Vibration training program

\begin{tabular}{|c|c|c|c|c|c|c|c|c|c|c|}
\hline & \multirow{2}{*}{$\begin{array}{l}\text { Duration } \\
\text { (s) }\end{array}$} & \multirow{2}{*}{$\begin{array}{l}\text { Frequency } \\
(\mathrm{Hz})\end{array}$} & \multirow{2}{*}{$\begin{array}{l}\text { Amplitude } \\
(\mathrm{mm})\end{array}$} & \multirow{2}{*}{$\begin{array}{l}\text { Rest } \\
\text { (s) }\end{array}$} & \multicolumn{5}{|c|}{ Number of series per exercise * } & \multirow[b]{2}{*}{$\mathrm{f}$} \\
\hline & & & & & $\mathrm{a}$ & $\mathrm{b}$ & $\mathrm{c}$ & $\mathrm{d}$ & $\mathrm{e}$ & \\
\hline Week 1 & 30 & 30 & 2 & 60 & 1 & 1 & 1 & 1 & 1 & 1 \\
\hline Week 2 & 30 & 30 & 2 & 60 & 2 & 1 & 1 & 1 & 1 & 1 \\
\hline Week 3 & 30 & 35 & 2 & 60 & 2 & 2 & 1 & 1 & 1 & 1 \\
\hline Week 4 & 30 & 35 & 2 & 40 & 2 & 2 & 2 & 1 & 1 & 1 \\
\hline Week 5 & 45 & 35 & 2 & 40 & 2 & 2 & 2 & 1 & 1 & 1 \\
\hline Week 6 & 45 & 40 & 4 & 40 & 3 & 2 & 2 & 1 & 1 & 1 \\
\hline Week 7 & 45 & 40 & 4 & 30 & 3 & 2 & 2 & 2 & 1 & 1 \\
\hline Week 8 & 60 & 40 & 4 & 30 & 3 & 2 & 2 & 2 & 1 & 1 \\
\hline Week 9 & 60 & 50 & 4 & 30 & 3 & 2 & 2 & 2 & 2 & 1 \\
\hline Week 10 & 60 & 50 & 4 & 30 & 3 & 3 & 2 & 2 & 2 & 2 \\
\hline
\end{tabular}

Note. * Exercises; a-Squat, b-Deep squat, c-Wide stance squat, d-Toes stand, e-Toes stand deep, f-Push up.

\subsection{Testing}

\subsubsection{Height}

The distance between the vertex spot of the head and the ground was measured for head measurements. During the measurement, the participants took off their shoes. They stayed as the heels joint and head in Frankfort position. The measurement results were recoded as $\mathrm{cm}$ (Lohman et al., 1988).

\subsubsection{Body Weight}

The weight of the body was determined with this measurement. The measurements of the body weight were made by using a digital scale (Seca 664, Hamburg, Germany) in bare feet and with only shorts (Utter et al., 1999; Sung et al., 2001; Nunez et al., 1997).

\subsubsection{Vertical Jump Test}

Jump height was measured using a jump-meter (Takei Scientific Instruments). The subjects were asked to give their body weights as equal to their both feet, bend their knees 90 degrees in average, not to take their stomachs to the front, not to bend their knees when they jumped, and they fall on the rubber area that had the shape of a circle. The vertical jumps of the individual completing his jump by falling on the rubber zone, and the best value after 2 trials are recorded as Vertical Jump Score in centimeters (Polman et al., 2004).

\subsubsection{Hand Grip Test}

It was ensured in the measurement that the volunteers used their dominant hands. It was adjusted to the length of the hand of the subject, and the digital dial was set to "0" point. The hand dynamometer (Takei-Grip-D, Takei Scientific Instruments, Tokyo, Japan) was kept at side in a position that was parallel to the body, and it was ensured that the arm was tightened as strongly as possible without moving it. The dynamometer was read and recorded in $\mathrm{kg}$. After each measurement, the subject was given a 10 -second resting time, and made two attempts. The best value was recorded (Komi, 2002; Beachle \& Earle, 2008).

\subsubsection{Sit and Reach Test}

For the measurement, the athlete sat as his feet in front of the table. In this position, he extended his body as far as possible, pushed the table down slowly, and stopped at the end. The test was repeated twice, and the best measurement was recorded (Wells \& Dillon, 2013).

\subsubsection{Agility T-Test}

Four cones are placed to prepare the track. The subject sprinted forward $9.14 \mathrm{~m}$. and touched the tip of the cone (B) with their right hand. Then they performed a lateral shuffle to the left $4.57 \mathrm{~m}$. and touched the tip of the cone (C) with the left hand. Subjects then shuffled $9.14 \mathrm{~m}$. to the right and touched the tip of the cone (D) with their right hand. They then shuffled $4.57 \mathrm{~m}$. to the left and touched cone (B) with their left hand. Finally, subjects back peddled $9.14 \mathrm{~m}$., passing through the finish at cone (A). The recorded score for this test was the better of the two last trials. Time was measured using a hand-held stopwatch. If a participant did not complete a trial successfully, " 0 " was given (Pauole et al., 2000).

\subsection{Statistical Analysis}

The results are given as mean \pm standard deviation. The values that were obtained from the pre-test and post-test were analyzed with the paired samples $t$ test after testing the normality distribution with the Shapire-Wilk Test. 
The comparisons between the groups were analyzed by using the independent samples $t$ test by considering the significance level of $\mathrm{p}<0.05$.

\section{Results}

The pre-test and post-test measurements of the WBV training group and control group are given below.

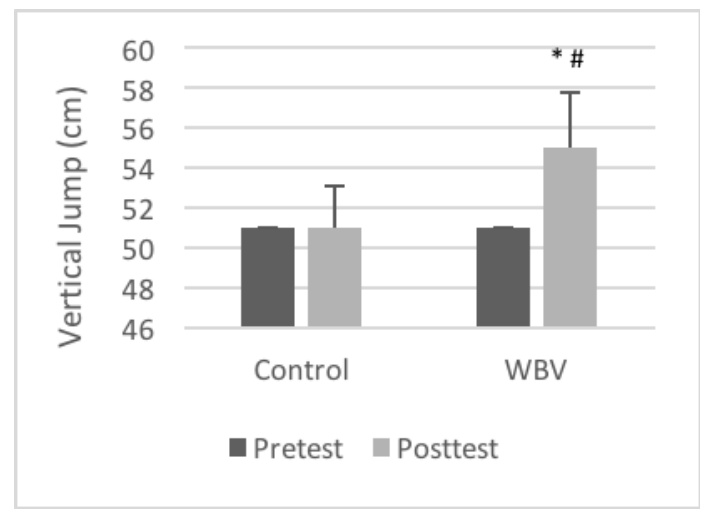

Figure 1. The mean and standard deviation pre and post vertical jump scores of the for WBV training group and control group

Note. ${ }^{*} \mathrm{p}<0.05$ significantly differences between pre and post value for each group. $\# \mathrm{p}<0.05$ significantly differences between groups.

When the vertical jump scores of the WBV training group and control group were compared, according to the Independent sample $t$ test, the pre-test scores of the WBV training group and control group were not found to be statistically significant $(\mathrm{p}=.451)$. A statistically significant difference was detected between the post-test scores of the WBV training group and the control group $(\mathrm{p}=.008)$. An increase was detected in the pre-test and post-test vertical jump scores of the WBV training group. According to the paired sample $t$ test, and according to the vertical jump scores, although the difference between the WBV training group pre-test and post-test results was significant $(\mathrm{p}=.008)$, the difference between the pre-test and post-test scores of the control group was not found to be significant ( $\mathrm{p}=.821$, Figure 1$)$.

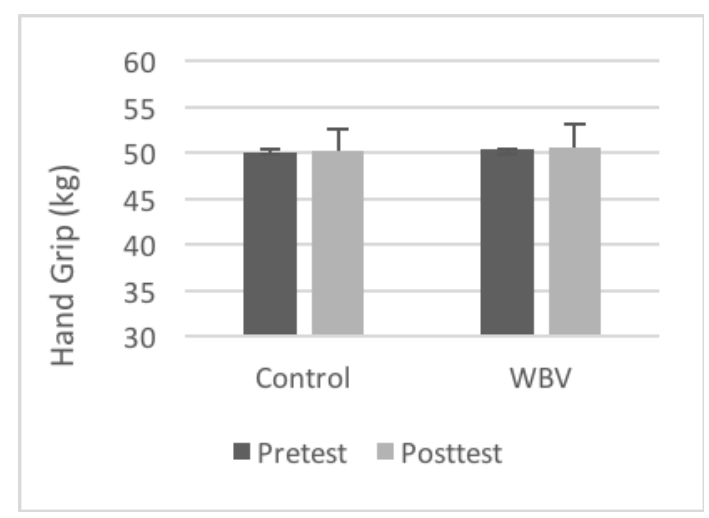

Figure 2. The mean and standard deviation pretest and posttest hand grip strength scores of the WBV training group and the control group

Note. ${ }^{*} \mathrm{p}<0.05$ significantly differences between pre and post value for each group. $\# \mathrm{p}<0.05$ significantly differences between groups.

When we compared the hand grip scores of the WBV training group and the control group according to the Independent sample $t$ test, the difference between the pre-test scores of the WBV training group and control group was not found statistically significant $(\mathrm{p}=.954)$. No statistically significant differences were detected between the post-test results of the WBV training group and control group $(\mathrm{p}=.614)$. There were no increases between pre-test and post-test scores of the WBV training group and control group in terms of hand grip strength 
values. According to the paired sample t test, and according to the hand grip strength scores, no statistically significant differences were found between the WBV training group pre-test and post-test scores $(p=.854)$. The difference between the control group pre-test and post-test scores was not found to be statistically significant $(\mathrm{p}=.913$, Figure 2$)$.

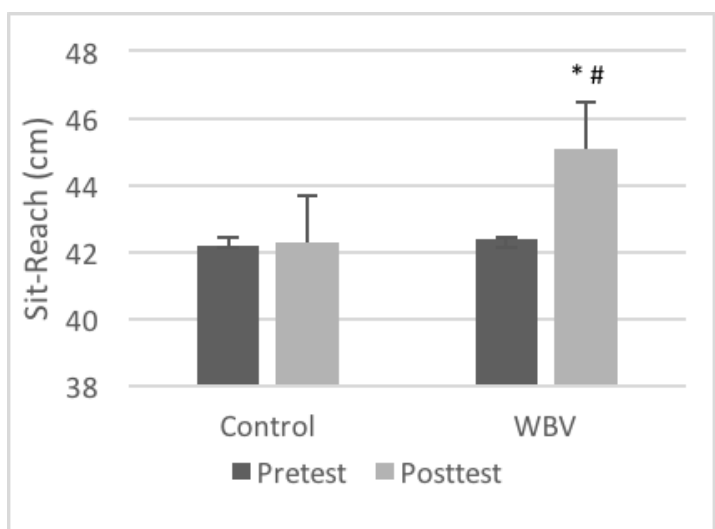

Figure 3. The mean and standard deviation pre-test and post-test sit-reach test scores of the WBV training group and control group

Note. ${ }^{*} \mathrm{p}<0.05$ significantly differences between pre and post value for each group. \# $\mathrm{p}<0.05$ significantly differences between groups.

When we examined the flexibility scores of the WBV training group and control group, according to the independent sample $t$ test the difference between WBV training group and control group was not statistically significant $(\mathrm{p}=.546)$. The post-test scores between the WBV training group and control group were statistically significant $(\mathrm{p}=.014)$. The WBV training group scores increased between the pre-test and post-test results in terms of the flexibility values. There were no changes in the control and posttest scores. According to the paired sample $t$ test, the difference between the pre-test and post-tests of the WBV training group was found to be statistically significant in flexibility values $(\mathrm{p}=.006)$. The difference between the pre-test and post-test scores of the control group was not found to be statistically significant $(\mathrm{p}=.714$, Figure 3$)$.

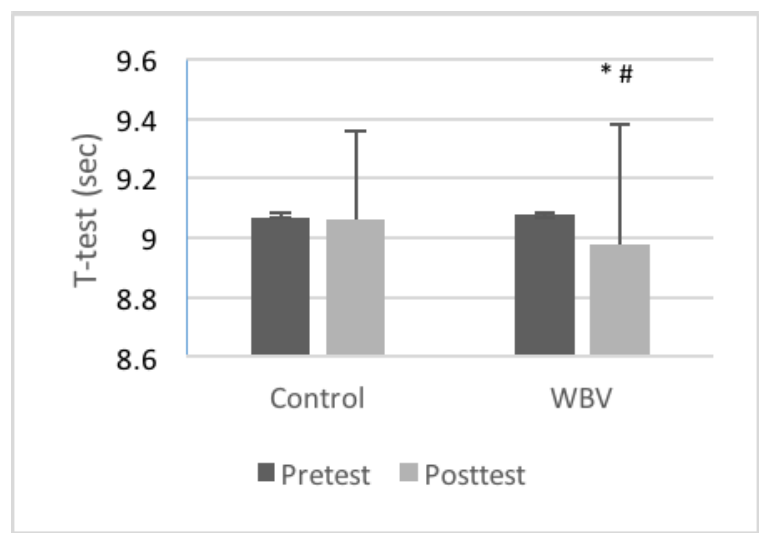

Figure 4. The mean and standard deviation pre-test and post-test scores for agility t-test in the WBV training group and control group

Note. ${ }^{*} \mathrm{p}<0.05$ significantly differences between pre and post value for each group. $\# \mathrm{p}<0.05$ significantly differences between groups.

When we compared the WBV training group and control group agility t-test scores according to the independent sample $\mathrm{t}$ test, the pre-test of the WBV training group and control group was not found to be statistically significant $(\mathrm{p}=.805)$. The difference between the post-test scores of the WBV training group and control group was statistically significant $(\mathrm{p}=.010)$. There were increases between pre-test and post-test scores in the WBV training group agility t-test. There were no changes between the pre-test and post-test scores of the control group. According to the paired sample $t$ test, and according to the agility t-test results, the difference between the 
pre-test and post-test results of the WBV training group was statistically significant $(\mathrm{p}=.011)$. The difference between the pre-test and post-test scores of the control group was not found to be statistically significant $(\mathrm{p}=.613$, Figure 4).

\section{Discussion}

In this study, to evaluate the upper extremity strength of the subjects, the hand grip strength was measured by using a hand dynamometer. After the 10-week training in the WBV training group, the hand grip strength increased at a statistically significant level. In the literature, there are not many studies to compare the upper extremity strength changes after long-term vibration exercises. It was reported that upper extremity strength increased as a result of vibration training that was applied for 3-4 weeks (Issurin et al., 1994; Kvorning et al., 2006).

Cochrane and Stannard (2005) reported no significant effect of WBV on hand grip test performance. They also stated that muscles that were not exposed to vibration directly showed less performance improvement when compared to directly vibrated muscles.

In this study, the lower extremity strength changes of the subjects were evaluated with vertical jump heights. When the studies that show the effects of long-term WBV trainings on lower extremity strength were examined, it was determined that very few studies reported no changes in this respect (De Ruiter et al., 2003; Torvinen et al. 2003). In many studies, studies reported increases in vertical jump height scores (Aksoy et al., 2017; Torvinen et al., 2002; Roelants et al., 2004b; Delecluse et al., 2003: Torvinen et al., 2003; Cochrane \& Stannard, 2005; Fagnani et al., 2006; Kinser et al., 2008,).

Short-term WBV training was shown to increase jump height scores (Bosco et al., 1998). In addition, acute WBV training was reported to increase jump height scores (Bosco et al., 2000). However, a decrease in jump performance was also found after a single training session (Rittweger et al., 2000). In this respect, Nordlund and Thorstensson (2007) examined 12 studies, and reported that WBV had little or no effects on jump performance scores.

In this study, the fact that there were increases in the strength of the lower-extremities after 10-week WBV training shows parallelism with the literature data.

In this study, the flexibility changes of the subjects were evaluated by sit and reach test. Some studies investigated the effects of acute WBV on flexibility in well-trained athletes, especially in gymnasts (Cochrane \& Stannard, 2005; Jacobs \& Burns, 2009; Despina et al., 2014; Dallas \& Kirialanis, 2013). According to the literature, there are findings showing that acute Whole Body Vibration training might increase flexibility (Cochrane et al., 2004; Cochrane \& Stannard, 2005; Fagnani et al., 2006).

Cochrane and Stannard (2005) conducted a study on elite female field hockey players, and reported that there were increases in the result of the sit and reach test after acute WBV training at a rate of $8.2 \%$. Fagnani et al. (2006) conducted a study with female athletes and determined improvements at a rate of $8.7 \%$ and $13 \%$ and the differences were found to be statistically significant.

It was reported that flexibility was increased in young gymnasts with local vibration application (Kinser et al., 2008). The improvement in the performance of the flexibility made us consider that the Ia inhibitor interneurons of the antagonist muscle might have activated after WBV training (Rothmuller \& Cafarelli, 1995).

In a study conducted previously, increases were detected in the flexibility scores of the subjects after the 4-week WBV trainings (van den Tillaar, 2006).

Most of the previous studies were conducted on the acute effects of WBV trainings. According to the literature, there were no studies with which we could compare the upper extremity strength values after long-term Whole Body Vibration trainings applied to elite athletes.

In this study, the agility t-test test measurements were made to evaluate the agility performances of the subjects. The agility t-test performance scores increased after 10-week in the WBV training group; and there was a statistically significant difference.

In a previous study, the effects of WBV training on acute strength was investigated; however, it was determined that there were no changes (Cochrane, 2013).

In a study that was conducted on short-term WBV training on non-elite individuals, WBV training was performed on 9 days and the agility performance was investigated. According to the agility test results, there were no changes between WBV training group and the control group (Cochrane et al., 2004). 
In another study, agility performance was measured after acute WBV training that was performed on female volleyball players. According to the agility test results, no significant differences were found between the pre-test and post-test results. However, there was a $0.48 \%$ improvement between the pre-test and post-test results (Hol et al., 2016).

According to the literature, there are no studies evaluating the effects of long-term WBV training in athletes. It is extremely difficult to compare the results of this study with some studies because of their methodological differences.

\section{Conclusion}

This paper studied on the effects of 10-week WBV trainings on strength, flexibility and agility in taekwondo athletes. Positive developments were detected in the vertical jump, flexibility and agility values of the taekwondo athletes who performed the WBV training.

Many studies in the literature examined the acute effects of WBV training. In these studies, it was determined that there were increases in the agility, flexibility and vertical jump values after acute WBV; and there were no positive increases in hand grip values. In addition, after the long-term WBV training, it was seen that vertical jump values increased. There are no studies conducted on the vertical jump, hand grip, flexibility and agility values of the Taekwondo athletes after long-term WBV training.

The injury risk in all body vibration training is less than that of any other classical training methods; and the training duration is low. For this reason, athletes may be encouraged to perform full body trainings. However, for the purpose of determining the chronic effects of WBV training in the literature, mostly untrained individuals or the individuals who dealt with recreational sports were examined. To evaluate different results, studies that will be conducted on athletes in different sports branches.

\section{References}

Adams, J. B., Edwards, D., Serravite, D. H., Serviette, D., Bedient, A. M., Huntsman, E., Jacobs, K. A., Del Rossi, G., \& Signorile, J. F. (2009). Optimal frequency, displacement, duration, and recovery patterns to maximize power output following acute whole-body vibration. Journal of Strength and Conditioning Research, 23, 237-245. https://doi.org/10.1519/JSC.0b013e3181876830

Aksoy, D., Erman, A., Balci, B., \& Senturk, U. K. (2017). Effect of protein intake on muscle strength and hypertrophy during whole-body vibration training. Isokinetics and Exercise Science, 25, 235-242. https://doi.org/10.3233/IES-171131

Beachle, T. R., \& Earle, W. R. (2008). Essentials of Strength Training and Conditioning. National Strength and Conditioning Association.

Behm, D. G., \& Chaouachi, A. (2011). A review of the acute effects of static and dynamic stretching on performance. European Journal of Applied Physiology, 111, 2633-2651. https://doi.org/10.1007/s00421-011-1879-2

Bosco, C., Cardinale, M., Tsarpela, O., Colli, R., Tihanyi, J., Duvillard, V., \& Viru, A. (1998). The influence of whole body vibration on jumping performance. Biology of Sport, 15, 157-164.

Bosco, C., Colli, R., Introini, E., Cardinale, M., Tsarpela, O., Madella, A., Tihanyi, J., \& Viru, A. (1999). Adaptive responses of human skeletal muscle to vibration exposure. Clinical Physiology, 19, 183-187. https://doi.org/10.1046/j.1365-2281.1999.00155.x

Bosco, C., Iacovelli, M., Tsarpela, O., Cardinale, M., Bonifazi, M., Tihanyi, J., Viru, M., De Lorenzo, A., \& Viru, A. (2000). Hormonal responses to whole-body vibration in men. European Journal of Applied Physiology, 81, 449-454. https://doi.org/10.1007/s004210050067

Bullock, N., Martin, D. T., Ross, A., Rosemond, C. D., Jordan, M. J., \& Marino, F. E. (2008). Acute effect of whole-body vibration on sprint and jumping performance in elite skeleton athletes. Journal of Strength and Conditioning Research, 22, 1371-1374. https://doi.org/10.1519/JSC.0b013e31816a44b5

Cochrane, D. J., \& Stannard, S. R. (2005). Acute whole body vibration training increases vertical jump and flexibility performance in elite female field hockey players. British Journal of Sports Medicine, 39, 860-865. https://doi.org/10.1136/bjsm.2005.019950

Cochrane, D. J. (2013). The effect of acute vibration exercise on short-distance sprinting and reactive agility. Journal of Sports Science and Medicine, 12(3), 497-501. 
Cochrane, D. J., Legg, S. J., \& Hooker, M. J. (2004). The short-term effect of whole-body vibration training on vertical jump, sprint, and agility performance. Journal of Strength and Conditioning Research, 18(4), 828-832.

Colson, S. S., Pensini, M., Espinosa, J., Garrandes, F., \& Legros, P. (2010). Whole-body vibration training effects on the physical performance of basketball players. Journal of Strength and Conditioning Research, 24(4), 999-1006. https://doi.org/10.1519/JSC.0b013e3181c7bf10

Dadebo, B., White, J., \& George, K. P. (2004). A survey of flexibility training protocols and hamstring strains in professional football clubs in England. British Journal of Sports Medicine, 38, 388-394. https://doi.org/10.1136/bjsm.2002.000044

Dallas, G., Kaimakamis, V., Melos, V., \& Parasidis, G. (2012). Acute effect of whole-body vibration combined with stretching on bridge performance in artistic gymnasts. Journal of Biology of Exercise, 8, 47-57. https://doi.org/10.4127/jbe.2012.0059

Dallas, G., \& Kirialanis, P. (2013). The effect of two different conditions of whole-body vibration on flexibility and jumping performance on artistic gymnasts. Science of Gymnastics Journal, 5, 67-77.

De Ruiter, C. J., van Raak, S. M., Schilperoort, J. V., Hollander A. P., \& de Haan, A. (2003). The effects of 11 weeks whole body vibration training on jump height, contractile properties and activation of human knee extensors. European Journal of Applied Physiology, 90, 595-600. https://doi.org/10.1007/s00421-003-0931-2

Delecluse, C., Roelants, M., \& Verschueren, S. (2003). Strength Increase After Whole Body Vibration Compared with Resistance Training. Medicine and Science in Sports and Exercise, 35(6), 1033-1041. https://doi.org/10.1249/01.MSS.0000069752.96438.B0

Despina, T., George, D., George, T., Sotiris, P., Alessandra, D. C., George, K., Maria, R., \& Stavros, K. (2014). Short-term effect of whole-body vibration training on balance, flexibility and lower limb explosive strength in elite rhythmic gymnasts. Human Movement Science, 33, 149-158. https://doi.org/10.1016/j.humov.2013.07.023

Fagnani, F., Giombini, A., Di Cesare, A., Pigozzi, F., \& Di Salvo, V. (2006). The effects of a whole- body vibration program on muscle performance and flexibility in female athletes. American Journal of Physical Medicine and Rehabilitation, 85, 956-962. https://doi.org/10.1097/01.phm.0000247652.94486.92

Fernandez-Rio, J., Terrados, N., \& Suman, O. (2012). Long-term effects of whole-body vibration training in high-level female basketball players. Journal of Sports Medicine and Physical Fitness, 52(1),18-26.

Fort, A., Romero, D., Bagur, C., \& Guerra, M. (2012). Effects of whole-body vibration training on explosive strength and postural control in young female athletes. Journal of Strength and Conditioning Research, 26(4), 926-936. https://doi.org/10.1519/JSC.0b013e31822e02a5

George, D., Vasilis, K., Vasilis, M., \& Giorgos, P. (2012). Acute effect of whole-body vibration combined with stretching on bridge performance in artistic gymnasts. Journal of Biology of Exercise, 8, 47-57. https://doi.org/10.4127/jbe.2012.0059

Giorgos, P., \& Elias, Z. (2007). Effects of whole-body vibration training on sprint running kinematics and explosive strength performance. Journal of Sports Science and Medicine, 6, 44-49.

Hol, C. S., Chang, C. Y., Lin, K. C., Chang, C. H., \& Chen, K. C. (2016, July). The Acute Effect of Whole Body Vibration Training on Agility, Speed and Power in Male Volleyball Players. 34rd 1nternational Conference on Biomechanics in Sports, Tsukuba, Japan.

Issurin, V. B., Liebermann, D. G., \& Tenenbaum, G. (1994). Effect of vibratory stimulation training on maximal force and flexibility. Journal of Sports Science and Medicine, 12, 561-566. https://doi.org/10.1080/02640419408732206

Jacobs, P. L., \& Burns, P. (2009). Acute enhancement of lower-extremity dynamic strength and flexibility with whole-body vibration. Journal of Strength and Conditioning Research, 23, 51-57. https://doi.org/10.1519/JSC.0b013e3181839f19

Kinser, A. M., Ramsay, M. W., O'Bryant, H. S., \& Ayres, C. A. (2008). Vibration and stretching effects on flexibility and explosive strength in young gymnasts. Medicine and Science in Sports and Exercise, 40, 133-140. https://doi.org/10.1249/mss.0b013e3181586b13 
Komi, P. V. (2002). Strength and Power in Sports (2nd ed.). IOC Medical Commision, International Federation of Sports Medicine.

Kvorning, T., Bagger, M., Caserotti, P., \& Madsen, K. (2006). Effects of Vibration and Resistance Training on Neuromuscular and Hormonal Measures. European Journal of Applied Physiology, 96, 615-625. https://doi.org/10.1007/s00421-006-0139-3

Kwok, H. H. M. (2012). Discrepancies in fighting strategies between Taekwondo medalists and non-medalists. Journal of Human Sport and Exercise, 7(4), 806-814. https://doi.org/10.4100/jhse.2012.74.08

Lohman, T. G., Roche, A. F., \& Martorell, R. (1988). Antropometric Standartization Referance Manual. Human Kinetics Books Champaigne, Illinois

Luo, J., McNamara, B., \& Moran, K. (2005). The use of vibration training to enhance muscle strength and power. Sports Medicine, 35, 23-41. https://doi.org/10.2165/00007256-200535010-00003

Machado, A., García-López, D., González-Gallego, J., \& Garatachea, N. (2010). Whole-body vibration training increases muscle strength and mass in older women. Scandinavian Journal of Medicine and Science in Sports, 20(1), 200-207.

Mahieu, N. N., Witvrouw, E., Van de Voorde, D., Michilsens, D., Arbyn, V., Van den, \& Broecke W. (2006). Improving strength and postural control in young skiers: whole-body vibration versus equivalent resistance training. Journal of Athletic Training, 41, 286-293.

Margarita, E. G., Pavlos, E. E., Stavros, T., \& Giorgos, P. P. (2013). Acute effects of dynamic whole body vibration in well trained track and field sprinters. Journal of Physical Education and Sport, 13, 270-277.

Norlund, M. M., \& Thorstensson, A. (2007). Strength training effects of whole-body vibration? Scandinavian Journal of Medicine and Science in Sport, 17(1),12-17.

Nunez, C., Gallagher, D., Visser, M., P1 Sunyer, F. X., Wang, Z., \& Heymsfield, S. B. (1997). Bioimpedance Analysis: Evaluation of Leg to Leg System Based on Pressure Contact Foot-pad Electrodes. Medicine and Science in Sports and Exercise, 29(4), 525-531.

Pauole, K., Madole, K., Garhammer, J., Lacourse, M., \& Rozenek, R. (2000). Reliability and validity of the T-test as a measure of agility, leg power, and leg speed in college-aged men and women. Journal of Strength and Conditioning Research, 14(4), 443-450.

Petit, P. D., Pensini, M., Tessaro, J., Desnuelle, C., Legros, P., \& Colson, S. S. (2010). Optimal whole-body vibration settings for muscle strength and power enhancement in human knee extensors. Journal of Electromyography and Kinesiology, 20, 1186-1195. https://doi.org/10.1016/j.jelekin.2010.08.002

Polman, R., Wals, D., Bloomfield, J., \& Nesti, M. (2004). Effective Conditioning of Female Soccer Players. Journal of Sports Sciences, 22, 191-203. https://doi.org/10.1080/02640410310001641458

Rittweger J., Schiessl, H., \& Felsenberg, D. (2001). Oxygen uptake in Whole Body Vibration Exercise: Comparison with Squatting as a Slow Voluntary Movement. European Journal of Applied Physiology, 86, 169-173. https://doi.org/10.1007/s004210100511

Rittweger, J., Beller, G., \& Felsenberg, D. (2000). Acute physiological effects of exhaustive whole-body vibration exercise in man. Clinical Physiology and Functional Imaging, 20(2), 134-142. https://doi.org/10.1046/j.1365-2281.2000.00238.x

Roelants, M., Delecluse, C., Goris, M., \& Verschueren, S. (2004a). Effects of 24 Weeks of Whole Body Vibration Training on Body Composition and Muscle Strength in Untrained Females. International Journal of Sports Medicine, 25(1), 1-5. https://doi.org/10.1055/s-2003-45238

Roelants, M., Delecluse, C., \& Verschueren, S. M. (2004b). Whole-Body-Vibration Training Increases Knee-Extension Strength and Speed of Movement in Older Women. The Journal of the American Geriatrics Society, 52, 901-908. https://doi.org/10.1111/j.1532-5415.2004.52256.x

Ronnestad, B. R. (2004). Comparing the performance-enhancing effects of squats on a vibration platform with conventional squats in recreationally resistance-trained men. Journal of Strength and Conditioning Research, 18(4), 839-845.

Rothmuller, C., \& Cafarelli, E. (1995). Effect of vibration on antagonist muscle activation during progressive fatigue in humans. Journal of Physiology, 485, 857-864. https://doi.org/10.1113/jphysiol.1995.sp020775 
Samson, M., Button, D. C., Chaouachi, A., \& Behm, D. G. (2012). Effects of dynamic and static stretching within general and activity specific warm-up protocols. Journal of Sport Science and Medicine, 11, 279-285.

Savelberg, H. H. C. M., Keizer, H. A., \& Meijer, K. (2007). Whole-body vibration induced adaptation in knee extensors; consequences of initial strength, vibration frequency, and joint angle. The Journal of Strength and Conditioning Research, 21, 589-593.

Shirley, S. M. F., \& Gabriel, Y. F. (2011). Does Taekwondo training improve physical fitness? Physical Therapy in Sport, 12, 100-106. https://doi.org/10.1016/j.ptsp.2010.07.001

Siegmund, L. A., Barkley, J. E., Knapp, D., \& Peer, K. S. (2014). Acute effects of local vibration with biomechanical muscle stimulation on low-back flexibility and perceived stiffness. Athletic Training and Sports Health Care, 6, 37-45. https://doi.org/10.3928/19425864-20140115-01

Sitjà-Rabert, M., Rigau, D., Fort, Vanmeerghaeghe, A., Romero-Rodríguez, D., Bonastre Subirana, M., \& Bonfill, X. (2012). Efficacy of whole body vibration exercise in older people: a systematic review. Disability and Rehabilitation, 34(11), 883-893. https://doi.org/10.3109/09638288.2011.626486

Sung, R. Y. T., Lau, P., Yu, C. W., Lam, P. K. W., \& Nelson, E. A. S. (2001). Measurement of Body Fat Using Leg to Leg Bioimpedance. Archives of Disease in Childhood, 85, 263-276. https://doi.org/10.1136/adc.85.3.263

Torvinen, S., Kannus, P., \& Sievanen, H. (2002). Effect of Four-Month Vertical Whole Body Vibration on Performance and Balance. Medicine and Science in Sports and Exercise, 34, 1523-1528. https://doi.org/10.1097/00005768-200209000-00020

Torvinen, S., Kannus, P., Sievanen, H., Jarvinen, T. A. H., Pasanen, M., Kontulainen, S., Nenonen, A., Jarvinen, T. L. N., Paakkala, T., Jarvinen, M., \& Vuori, I. (2003). Effect of 8-Month Vertical Whole Body Vibration on Bone, Muscle Performance, and Body Balance: A Randomized Controlled Study. Journal of Bone and Mineral Research, 18(5) ,876-884. https://doi.org/10.1359/jbmr.2003.18.5.876

Utter, A. C., Nieman, D. C., Ward, A. N., \& Butterworth, D. E. (1999). Use of The Leg to Leg Bioelectrical Impedance Metod in Assessing Body Composition Change in Obese Women. The American Journal of Clinical Nutrition, 60, 603-607. https://doi.org/10.1093/ajcn/69.4.603

van den Tillaar, R. (2006). Will whole-body vibration training help increase the range of motion of the hamstrings? Journal of Strength and Conditioning Research, 20(1),192-196.

Wells, K. F., \& Dillon, E. K. (1952). The sit-and-reach. A test of back and leg flexibility. The Research Quarterly, 23, 115-118. https://doi.org/10.1080/10671188.1952.10761965

\section{Copyrights}

Copyright for this article is retained by the author, with first publication rights granted to the journal.

This is an open-access article distributed under the terms and conditions of the Creative Commons Attribution license (http://creativecommons.org/licenses/by/4.0/). 